
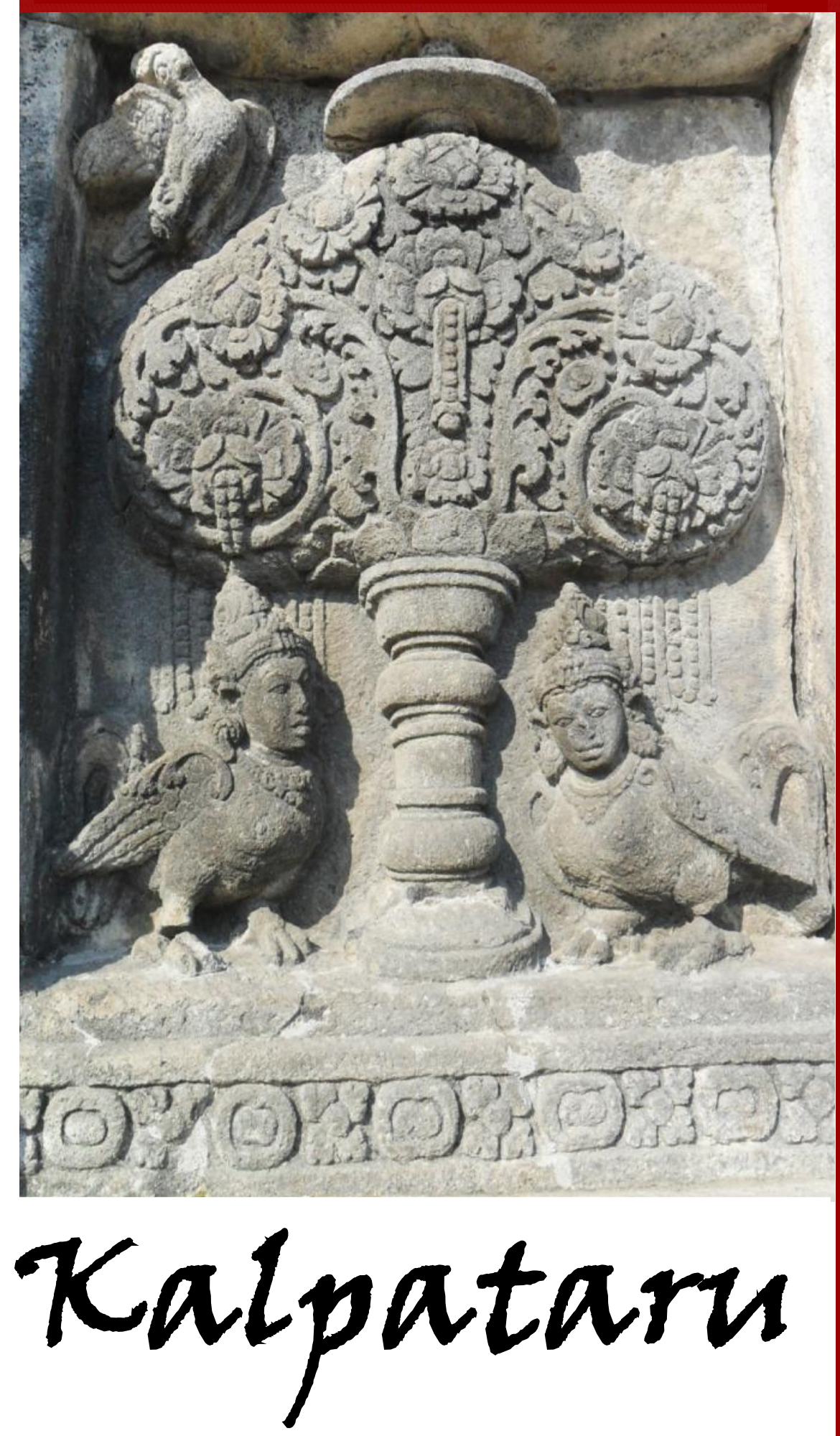

JURNAL SEJARAH DAN PEMBELAJARAN SEJARAH

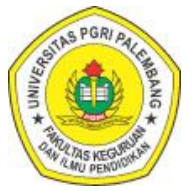

Program Studi Pendidikan Sejarah Jurusan Pendidikan IPS

Fakultas Keguruan dan IImu Pendidikan Universitas Persatuan Guru Republik Indonesia Palembang
Kajian Tata Ruang Lukisan Dinding Pada Batu Balai di Desa Tegur Wangi Lama Kota Pagaralam Sebagai Sumber Pembelajaran Sejarah

Muhammad Randi Saputra, H. Rudi Asri

Nilai Sejarah Toponim di Kecamatan Bukit Kecil Kota Palembang Sebagai Sumber Pembelajaran Sejarah di SMP Negeri 33 Palembang

Dedi Berianto

Upaya Meningkatkan Kualitas Pembelajaran Sejarah Melalui Penerapan Outdoor Learning Berbasis Inkuiri di SMA Muhammadiyah 1 Palembang

Arman, Fatmah

Senjang: Sejarah Tradisi Lisan Masyarakat Musi Banyuasin

Brian Apriadi, Eva Dina Chairunisa

Peningkatan Hasil Belajar dan Aktifitas Siswa Melalui Model Pembelajaran Discovery Learning di SMA Negeri 8 Palembang

Sri Mulyati, Nurhayati Dina, Apriana

Jenis-Jenis Peninggalan Megalit di Desa Tanjung Aro Sebagai Sumber Pembelajaran Sejarah di Kelas X SMA Muhammadiyah 3 Palembang Tahun Ajaran 2017/2018

Lita Sepriani

Persepsi Siswa Terhadap Penggunaan Media Film Dokumenter Materi Kehidupan Manusia Purba Pada Mata Pelajaran Sejarah di SMK Negeri 6 Palembang M. Edo Nuryana

Sejarah Tulung Selapan Sebagai Sumber Penulisan Sejarah Lokal Ogan Komering Ilir

Muhamad Idris

Pengaruh Model Pembelajaran Explicit Instruction Terhadap Hasil Belajar Siswa Pada Mata Pelajaran Sejarah di Sekolah Menengah Atas Negeri 1 Gelumbang Ramoni Handayani

Pengaruh Penggunaan Media Film Dokumenter Terhadap Hasil Belajar Siswa Pada Mata Pelajaran Sejarah di Sekolah Menengah Atas Sriguna Palembang Vina Pratiwi 


\section{Kalpataru}

Jurnal Sejarah dan Pembelajaran Sejarah

Volume 4, Nomor 2, Desember 2018

Penanggung Jawab

Dr. Dessy Wardiah, M.Pd.

Ketua Dewan Redaksi

Drs. Sukardi, M.Pd.

\section{Penyunting Pelaksana}

Muhamad Idris, M.Pd.

Eva Dina Chairunisa, M.Pd.

Jeki Sepriady, S.Pd.

Dr. Tahrun, M.Pd.

Drs. Supriyanto, M.Hum.

Dra. Retno Purwati, M.Hum.

Dr. Nor Huda Ali, M.Ag., M.A.

Budi Agung Sudarman, S.S., M.Pd.

Dr. Purmansyah, M.A.

\section{Penyunting Ahli}

(Universitas PGRI Palembang)

(Universitas Sriwijaya Palembang)

(Balai Arkeologi Sumatera Selatan)

(Masyarakat Sejarawan Indonesia Sumsel)

(Balai Bahasa Provinsi Sumatera Selatan)

(Universitas Muhammadiyah Palembang)

\section{Alamat Redaksi}

Program Studi Pendidikan Sejarah

Jurusan Pendidikan IImu Pengetahuan Sosial

Fakultas Keguruan dan IImu Pendidikan Universitas PGRI Palembang

Telp. 0711-510043

Email: jurnalkalpatarusejarah@gmail.com

Website: https://jurnal.univpgri-palembang.ac.id/index.php/Kalpa 


\section{Kalpataru}

\author{
JURNAL SEJARAH DAN
}

PEMBELAJARAN SEJARAH

Terbit dua kali setahun pada Juli dan Desember

Diterbitkan oleh:

Program Studi Pendidikan Sejarah Jurusan Pendidikan IPS

Fakultas Keguruan dan IImu Pendidikan Universitas PGRI Palembang

\section{Gambar Cover: \\ Pohon Kalpataru \\ Candi Prambanan}

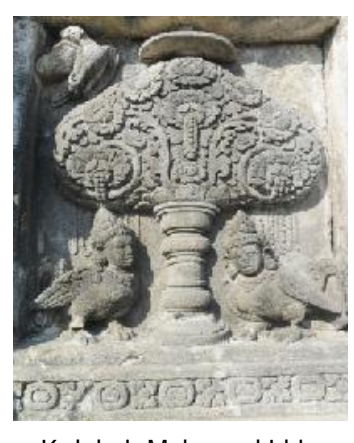

Koleksi: Muhamad Idris

\section{DAFTAR ISI}

Kajian Tata Ruang Lukisan Dinding Pada Batu Balai di Desa Tegur Wangi Lama Kota Pagaralam Sebagai Sumber Pembelajaran Sejarah

Muhammad Randi Saputra, H. Rudi Asri. $.89-98$

Nilai Sejarah Toponim di Kecamatan Bukit Kecil Kota Palembang Sebagai Sumber Pembelajaran Sejarah di SMP Negeri 33 Palembang

Dedi Berianto. 99-110

Upaya Meningkatkan Kualitas Pembelajaran Sejarah Melalui Penerapan Outdoor Learning Berbasis Inkuiri di SMA Muhammadiyah 1 Palembang

Arman, Fatmah.

Senjang: Sejarah Tradisi Lisan Masyarakat Musi Banyuasin

Brian Apriadi, Eva Dina Chairunisa

Peningkatan Hasil Belajar dan Aktifitas Siswa Melalui Model Pembelajaran Discovery Learning di SMA Negeri 8 Palembang

Sri Mulyati, Nurhayati Dina, Apriana.

Jenis-Jenis Peninggalan Megalit di Desa Tanjung Aro

Sebagai Sumber Pembelajaran Sejarah di Kelas X SMA

Muhammadiyah 3 Palembang Tahun Ajaran 2017/2018

Lita Sepriani..

Persepsi Siswa Terhadap Penggunaan Media Film Dokumenter Materi Kehidupan Manusia Purba Pada Mata Pelajaran Sejarah di SMK Negeri 6 Palembang M. Edo Nuryana.

Sejarah Tulung Selapan Sebagai Sumber Penulisan Sejarah Lokal Ogan Komering Ilir Muhamad Idris. $146-153$

Pengaruh Model Pembelajaran Explicit Instruction Terhadap Hasil Belajar Siswa Pada Mata Pelajaran Sejarah di Sekolah Menengah Atas Negeri 1 Gelumbang

Ramoni Handayani. 154-161

Pengaruh Penggunaan Media Film Dokumenter Terhadap Hasil Belajar Siswa Pada Mata Pelajaran Sejarah di Sekolah Menengah Atas Sriguna Palembang

Vina Pratiwi. $162-169$ 


\title{
NILAI SEJARAH TOPONIM DI KECAMATAN BUKIT KECIL KOTA PALEMBANG SEBAGAI SUMBER PEMBELAJARAN SEJARAH DI SMP NEGERI 33 PALEMBANG
}

\author{
Dedi Berianto \\ Guru Sejarah di SMA Pramula Palembang \\ Email: dediberianto@gmail.com
}

\begin{abstract}
ABSTRAK
Toponim merupakan sebuah ilmu yang berkaitan dengan penamaan suatu wilayah yang berguna memberikan informasi kepada masyarakat tentang asal usul penamaan suatu tempat. Pemberian nama oleh manusia mempermudah dalam mengindentifikasi suatu tempat tinggalnya, pemberian nama ini tidak asal diberikan karena manusia memberikan nama suatu tempat atau kawasan berdasarkan letak geografis, sejarah dan fenomena alam yang terjadi di tempat itu. Rumusan masalah penelitian ini adalah nilai sejarah apa saja yang terdapat pada toponim kecamatan Bukit Kecil sehingga dapat dijadikan sumber pembelajaran sejarah?. Penelitian ini bertujuan untuk mengetahui nilai sejarah apa saja yang terdapat pada toponim kecamatan Bukit Kecil sehingga dapat dijadikan sumber pembelajaran sejarah. Penelitian ini menggunakan metode deskriptif kualitatif, pengumpulan data dari wawancara, dokumentasi, dan observasi lapangan. Analisis data mulai dari reduksi data, penyajian data dan penarikan kesimpulan. Dari hasil penelitian dan pembahasan bahwa toponim yang ada di kecamatan Bukit Kecil terdapat nilai religius dan nilai persatuan yang dapat dijadikan sebagai sumber pembelajaran sejarah (IImu Pengetahuan Sosial) di Sekolah Menengah Pertama Negeri 33 Palembang.
\end{abstract}

Kata Kunci: Sejarah Toponim, Kecamatan Bukit Kecil, Sumber Pembelajaran Sejarah.

\section{A. PENDAHULUAN}

Palembang merupakan ibu kota provinsi Sumatera Selatan secara geografis terletak antara $2^{0} 52^{\prime}$ sampai $3^{0} 5^{\prime}$ lintang Selatan $104^{\circ}$ 37' sampai $104^{0}$ 52' bujur Timur dengan ketinggian rata-rata 8 meter dari permukaan air laut. Luas wilayah kota Palembang sebesar 400,61 $\mathrm{km}^{2}$ yang secara adminitrasi terbagi atas 16 kecamatan dan 104 kelurahan (Utomo, 2016:65). Kecamatan Bukit Kecil merupakan suatu kawasan pemukiman kolonial yang masih utuh keberadaannya seperti kawasan Talang Semut dan kantor Ledeng yang sekarang menjadi kantor wali kota Palembang yang beralamat di jalan Merdeka, kelurahan 22 llir. Selain kantor Ledeng ada juga sisa bangunan kolonial yaitu bangunan museum Sultan Mahmud Badaruddin II, Benteng Kuto Besak dan Kambang Iwak.

Pada masa Kesultanan Palembang Darussalam, kegiatan kota terkonsentrasi disepanjang tepi sungai Musi, sebagian besar aspek pemukiman berlokasi ditepi
Utara sungai, seperti bangunan keraton, masjid dan pemukiman rakyat. Setelah dihapuskannya Kesultanan Palembang Darussalam, wilayah ini dijadikan daerah administrasi Hindia-Belanda yang dipimpin oleh seorang residen. Pusat adminitrasi dilokasikan disekitar Benteng Kuto Besak yaitu bekas Keraton Kuto Lamo. Secara umum pembangunan fisik kota Palembang yang dilakukan oleh pemerintah HindiaBelanda dimulai pada awal abad XX Masehi (Aryandini, 2002:2). Sejak itu pusat pemerintahan kota Palembang dipindahkan ke lokasi baru yaitu disebelah Barat Benteng Kuto Besak, disebelah ini juga didirikan bangunan-bangunan umum seperti gedung peradilan, kantor pos dan telepon, rumah gadai, sekolah, gereja dan hotel (Elvian, 2009:105).

Secara konsentri keberadaan tempat tinggal masyarakat Palembang pada awalnya mengacu pada sungai-sungai yang membelah kota Palembang sebagai sarana kehidupan pada waktu itu. Keberadaan tempat tinggal masyarakat kemudian 
terkonsentrasi pula di kiri dan kanan jalan, karena proses pembentukan oleh kolonial Belanda, selanjutnya ada yang terkonsentrasi di sekitar keresidenan sebagai pusat pemerintahan (bestuur) dan dikawasan-kawasan tertentu dipusat perdagangan (pasar atau keramaian). Dengan demikian tata letak kampungkampung tersebut kemudian menyebar sesuai pusat-pusat konsentri diatas. Keberadaan kampung-kampung tersebut berkembang dan berproses sesuai dinamika perkembangan masyarakat dan budayanya. Namun demikian dinamika perkembangan dan perubahan tersebut masih tetap berpijak pada akar budaya masyarakat setempat (Elvian, 2009:105). Sampai saat ini toponim tersebut masih dapat dilacak keberadaannya karena kemudian menjadi nama-nama kampung.

Nama pada seorang manusia disebut nama diri, untuk membedakan nama diri yang sama dari lebih satu orang, maka ditambah dibelakang nama diri tersebut suatu nama kedua yang umumnya adalah nama bapaknya dalam masyarakat yang patriarchal. Selain nama manusia, semua objek yang ada disekitar kita seperti hotel, toko, klinik, dan sebagainya diberi nama oleh manusia untuk mengidentifikasi suatu objek dengan objek yang sama lainnya, nama diberikan untuk tujuan identifikasi, komunikasi dan informasi bagi sesama manusia. Begitu juga nama-nama pemukiman, kampung, desa dan sebagainya diberi nama oleh manusia untuk tujuan yang sama. Penamaan itu bedasarkan tanda-tanda alam yang mudah dikenal ditempat tersebut yang akhirnya menjadi nama desa atau kampung, tempat tinggal mereka (Rais, 2008:3).

Toponimi diartikan sebagai asal usul penamaan suatu tempat, pada dasarnya bahwa penulisan toponimi suatu daerah adalah merupakan suatu usaha yang dilakukan untuk menggali dan mengungkapkan perjalanan sejarah dan budaya yang dikandung oleh suatu toponimi. Melalui toponim kita dapat melihat kampung yang berkaitan dengan tempat tinggal masyarakat, maupun adanya fenomena sosial dan dinamika baru yang muncul sebagai konsekuensi dari perkembangan sebuah kota (Elvian, 2009:105). Toponim sebagai suatu jejak sejarah masa lampau tentang keberadaan sebuah kota, merupakan salah satu ciri dan penanda kota yang sangat bermanfaat bagi masyarakat terutama dalam memahami setiap filosofi kota yang telah diwariskan dan diperkenalkan oleh pendahulu atau tokoh kota pada waktu itu. Memahami dengan baik filosofi kota melalui jejak-jejak toponim yang ada, akan membawa kepada tindakan yang bijaksana terhadap perencanaan pembangunan dan pengembangan kota sebab melalui toponim dapat diselusuri karakteristik fisik, sosial, ekonomi dan budaya sebuah kota (Elvian, 2009:138).

Menurut Jeko (2014:3) dalam jurnalnya toponim suatu daerah merupakan identitas yang membedakannya dengan daerah lain, karena toponim merupakan hasil kebudayaan masyarakat suatu daerah yang bersumber dari hubungan timbal balik dengan lingkungan disekitarnya, baik aspek fisik maupun nonfisik. Unsur kebudayaan yang paling ketara dalam toponim yaitu bahasa. Indonesia sebagai bangsa yang majemuk terdiri dari banyak suku bangsa sehingga memiliki bahasa yang berbedabeda. Hal ini menyebabkan beranekaragamnya toponim di daerahdaerah Indonesia.

Salah satu bentuk toponim yang cukup menarik dan keberadaannya dapat menjadi identitas suatu tempat adalah toponim berdasarkan nama jalan di kecamatan Bukit Kecil kota Palembang yang terkandung nilai kesejarahan didalamnya. Bentuk seperti ini cukup banyak ditemukan di beberapa wilayah kecamatan Bukit Kecil, seperti Jl. KH. Ahmad Dahlan, Jl. Dipenogoro dan Jl. Kapten A. Rivai. Dengan hanya melihat tempat kejadian suatu peristiwa bersejarah dari lokasi pun dapat 
dengan mudah dikenali. Namun, karena perkembangan kota Palembang disertai dengan pertambahan jumlah penduduk yang semakin meningkat mengakibatkan perubahan pada gambaran kota Palembang pada masa kini. Toponim banyak yang belum tahu, keberadaan penanda seperti ini sangat penting sebagai pengingat dan penghubung suatu masyarakat atau area dengan sejarah masa lalu yang membentuknya.

Rumusan masalah penelitian ini adalah nilai sejarah apa saja yang terdapat pada toponim kecamatan Bukit Kecil sehingga dapat dijadikan sumber pembelajaran sejarah?. Penelitian ini bertujuan untuk mengetahui nilai sejarah apa saja yang terdapat pada toponim kecamatan Bukit Kecil sehingga dapat dijadikan sumber pembelajaran sejarah.

\section{B. METODE PENELITIAN}

Dalam penelitian ini peneliti menggunakan metode deskriprif kualitatif.

Pengumpulan data dapat dilakukan dalam berbagai seting. Berbagai sumber, dan berbagai cara. Pengumpulan data berdasarkan tekniknya yaitu melalui: observasi, dokumentasi dan wawancara.

Observasi: Mendatangi tempat lokasi penelitian dan melihat apa yang menjadi permasalahan dilapangan. Wawancara: Digunakan sebagai teknik pengumpulan data apabila peneliti ingin melakukan studi pendahuluan untuk menemukan masalah yang harus diteliti. Dokumentasi: Digunakan untuk mendapatkan data yang ada dilapangan seperti arsip, foto, dan dokumen yang menyimpan tentang penelitian.

\section{HASIL DAN PEMBAHASAN Toponim di Kecamatan Bukit Kecil Candi Walang}

Kawasan Candi Walang terletak di kelurahan 24 llir kecamatan Bukit Kecil. Di kawasan Candi Walang terdapat makam seorang sultan pada masa Kesultanan
Palembang Darussalam pada abad ke-17 Masehi, yakni Pangeran Ratu Kimas Hindi Sri Susuhan Abdurrahman Candi Walang Khalifatul Mukminin Sayidul Imam atau lebih dikenal Kimas Hindi/Kimas Cinde. Dugaan ini cukup beralasan karena di pasar Cinde terdapat komplek pemakaman Kesultanan Palembang.

Setelah keraton Kuto Gawang runtuh oleh serangan tentara VOC, Kemas Hindi memproklamirkan Kesultanan Palembang Darussalam dan melepaskan dari pengaruh kerajaan Mataram dan Demak (1643-1651). Sebab sebelumnya kerajaan Islam Palembang tunduk terhadap Demak dan Mataram. Mengapa pemakaman ini dinamakan Candi Walang, karena desain kubah tempat sang pangeran di makamkan berbentuk candi dan menjadi tempat favorit belalang hinggap. Sehingga dinamakan Candi Walang, Walang artinya berasal dari bahasa Jawa yang artinya belalang. Makamnya berdampingan dengan permaisuri susuhan dan mendiang sang guru Said Mustopa Al Idrus serta beberapa putri beliau dan panglima kesultanan. Bangunan asli gubah tempat sang pangeran di makamkan sudah banyak berubah dari awal dibangun. Semua bagian terbuat dari kayu tembesu dan diukir dengan sayatan ukiran asli Palembang, tapi sekarang bangunan sudah rapuh, beberapa platfon atas sudah berlubang (Konfrontasi).

Di kawasan Candi Walang terdapat pasar Cinde yang terletak di pusat kota Palembang dengan batas Utara pada $\mathrm{Jl}$. Letnan Jaimas, sebelah Selatan JI. Cinde Welan; sebelah Timur Jl. Sudirman dan sebelah Barat merupakan makam dari Sultan Abdurrakhman Khifatul Mukminim Sayyidul Imam (pendiri Kesultanan Palembang). Dahulu pasar ini disebut dengan pasar Lingkis, karena dulunya banyak pedagang yang berasal dari daerah Lingkis, Jejawi, Ogan Komering llir. Pasar tradisional yang berlokasi di lapangan terbuka didepan makam dan berdampingan dengan terminal bis antar kota. 
Arsitek yang membangun pasar Cinde adalah Herman Thomas Karsten (1884-1995), namun pembangunannya dimulai pada 1958. Arti nama pasar ini adalah "cindo" atau bagus. Penamaan tempat ini cukup beralasan karena pada beberapa puluh tahun yang lalu menganggap bahwa barang-barang yang dijual di pasar ini adalah barang berkualitas bagus, khususnya hasil bumi, peternakan dan perikanan.

Dapat disimpulakan bahwa toponim kawasan Candi Walang terdapat makam pendiri Kesultanan Palembang Darussalam yakni Pangeran Ratu Kimas Hindi Sri Susuhan Abdurrahman Candi Walang Khalifatul Mukminin Sayidul Imam atau lebih dikenal Kimas Hindi/Kimas Cinde. Pada makam tersebut terdapat desain gubah yang berbentuk candi dan menjadi tempat favorit belalang hinggap.

\section{Benteng Kuto Besak}

Benteng Kuto Besak dibangun pada masa pemerintahan Mahmud Bahaudin (1776-1803). Kesultanan Palembang dari tahun 1812 hingga 1821 dihadapkan pada beberapa kali peperangan. Peperangan pada 1812 berhadapan dengan Inggris, sedangkan pada tahun 1819 terjadi dua kali peperangan melawan pihak kolonial Belanda. Puncaknya terjadi pada perang tahun 1821. Pada peperangan itu penguasa Palembang pada waktu itu yaitu Sultan Mahmud Badaruddin II harus mengakui keunggulan Belanda, sehingga di buang ke Ternate. Peristiwa tersebut menjadi akhir kedaulatan Palembang sebagai sebuah kesultanan yang merdeka. Berbagai peperangan tersebut, menyebabkan terjadinya "turun-naik" penguasa Palembang antara kakak-adik (Sultan Mahmud Badaruddin II, dan Sultan Ahmad Najamuddin II). Begitu pula singgasana tempat mereka berkuasa. Disebutkan bahwa penguasa sah akan berkedudukan di keraton Kuto Besak, sedangkan sultan yang diturunkan menempati keraton Lamo yang berada di sebelahnya. Begitu pula hal yang sama terjadi pada masa pemerintahan Belanda kedua sejak akhir tahun (Farida, 2013).

Kata "keraton" berasal dari bahasa Jawa, kata dasarnya "ratu" yang berarti "penguasa". Kata ini mendapat awalan "ke" akhiran "an" sehingga menjadi ke-ratuan. Dari keratuan inilah menjadi "keraton". Selanjutnya keraton dimaknai sebagai tempat seorang penguasa yaitu raja atau ratu memerintah, sekaligus berfungsi sebagai tempat tinggal. Dengan demikian, keraton adalah lambang supremasi, begitu pula Kuto Besak yang merupakan satusatunya bangunan yang paling kokoh, dan terletak di lokasi yang sangat strategis di kesultanan Palembang. Sementara itu, Kuto Besak selama ini dinamai Benteng Kuto Besak (BKB). Benteng adalah suatu infrastruktur yang berkaitan erat untuk kepentingan militer, dan dominasi kekuasaan. Dengan demikian, benteng berkaitan erat dengan strategi bertahan (tempat bertahan jika mendapat serangan dari musuh). Agar strategi itu efektif, maka benteng tersebut harus berada di lokasi yang strategis (Farida, 2013).

Benteng didefinisikan sebagai lokasi militer atau bangunan yang didirikan secara khusus diperkuat dan tertutup yang dipergunakan untuk melindungi tempat instalasi, daerah atau sepasukan tentara dari serangan musuh atau untuk menguasai suatu daerah. Kuto Besak merupakan keraton pusat Kesultanan Palembang Darussalam, menurut kamus bahasa Jawa kuno pengertian kuto berasal dari kata sansekerta yang berarti: kota, puri, benteng atau kubu. Kuto Besak adalah simbol kerajaan, tempat sultan memerintah seluruh wilayah kerajaannya yang membentang dari Ampat Lawang dan Rejang di sebelah Barat, Rawas di sebelah Utara, Kisam dan Makakau di Selatan, serta Pulau BangkaBelitung di sebelah Timur.

Dapat disimpulkan bahwa toponim kawasan Benteng Kuto Besak memilliki arti 
sebagai pertahan militer pada masa Kesultanan Palembang Darussalam, dalam perjalanan sejarahnya Benteng Kuto Besak selain berfungsi sebagai tempat tinggal Sultan Palembang Darussalam, benteng ini juga berfungsi sebagai bangunan pertahanan. Ketika Kesultanan Palembang Darussalam dihapuskan oleh pemerintah Hindia Belanda, fungsi Benteng Kuto Besak lebih diutamakan menjadi instalasi militer, meskipun demikian didalam benteng juga berfungsi sebagai tempat tinggal komisaris Hindia-Belanda, pejabat pemerintahan dan perwira militer.

\section{Guguk Pengulon}

Guguk Pengulon terletak di kelurahan 19 Ilir, Guguk Pengulon memiliki nilai sejarah yang tinggi, di sekitar lokasi ini berdiri keraton Kesultanan Palembang Darussalam pada abad ke-18 Masehi. Kawasan pusat pemerintahan kesultanan ini meninggalkan warisan yang begitu penting dan berharga, diantaranya ialah Masjid Agung, Benteng Kuto Besak, pemukiman para alim ulama dan lain sebagainya. Para alim ulama, waliyullah, dan pejabat agama pada masa Kesultanan Palembang Darussalam yang sebagian besar berdomisili serta tinggal di "Guguk Pengulon" (Aryandininovita).

Kata pengulon artinya kepenghuluan, dilingkungan masjid Agung Palembang oleh sebab itu disebut Guguk kampung Pengulon. Permukiman tua melingkari masjid. Rumah-rumah panggung terbuat dari papan, tetapi kokoh dan tetap tegak, meski dimakan usia. Permukiman itu tumbuh sepanjang usia masjid yang dibangun Sultan Mahmud Badaruddin Jayo Wikramo pada tahun 1738 hingga tahun 1748. Kini, pemandangan lingkungan tua yang padat itu sudah berubah. Masjid Agung diperluas, dipercantik, dan diresmikan Presiden Megawati Soekarno Putri, Juni 2003 lalu. Jalan lingkar masjid diperluas, tentu saja puluhan rumah panggung tersingkir dari kawasan itu.
Di ujung jalan lingkar Barat masjid terpasang papan nama jalan Faqih Jalaluddin. Bersambung ke sisi Utara masjid, terdapat ruas jalan pendek, kurang dari 100 meter, yang baru beberapa bulan lalu dinamai jalan Tjek Agus Kiemas, nama mendiang ayah Taufik Kiemas, suami mantan Presiden Megawati. Meskipun papan nama jalan terpancang jelas, orangorang, terutama orang tua di ibu kota Palembang, masih menyebut jalan lingkar masjid itu sebagai jalan Guru-guru. Hingga tahun 1980-an, kawasan ini masih dikenal sebagai "Guguk Pengulon" yang berarti permukiman para penghulu atau ahli agama tapi banyak orang yang tidak tahu perputaran ekonomi dari jajanan pasar di daerah ini. Pemukiman ini dapat pula bersifat aspiratif, yaitu satu guguk yang mempunyai satu profesi atau kedudukan yang sama, seperti Guguk Pengulon, pemukiman para pendahulu dan alim ulama disekitaran masjid Agung. Demikian pula dengan Kedemangan, wilayah dimana tokoh demang tinggal, ataupun Kebumen yaitu tempat-tempat dimana Mangkubumi menetap.

Guguk dijadikan beberapa kampung. Sebagai kepala diangkat menjadi kepala kampung, dan Palembang dibagi menjadi dua wilayah, yaitu Seberang Ulu dan Seberang Ilir. Untuk mengepalai wilayah tersebut diangkat menjadi Demang. Demang adalah pamong praja pribumi yang tunduk kepada controleur. Kota Palembang pada waktu itu terdiri dari 52 kampung, yaitu 36 kampung berada di Seberang Ilir dan 16 kampung di Seberang Ulu. Kampungkampung ini diberi yaitu dari nomor 1 sampai 36 untuk Seberang llir, sedangkan Seberang Ulu dari 1 sampai 16 Ulu. Pemberian nomor-nomor kampung ini penuh semangat pada awal pelaksanaannya, tetapi kemudian pembagian tidak berkembang malah menyusut. Pada tahun 1939 kampung tersebut menjadi 43 buah, dimana 29 kampung berada di Seberang llir dan 14 
kampung berada di Seberang Ulu (Santun, 2010:56).

Dapat disimpulkan bahwa toponim kawasan Guguk Pengulon yang terletak di kelurahan 19 Ilir kecamatan Bukit Kecil memiliki arti yakni Guguk artinya satu profesi atau kedudukan yang sama sedangkan Pengulon artinya penghulu. Pada masa Kesultanan Palembang Darussalam, di kawasan Guguk Pengulon merupakan permukiman para penghulu atau ahli agama.

\section{Talang Semut}

Kawasan Talang Semut berada di kelurahan Talang Semut kecamatan Bukit Kecil. Memasuki zaman kolonial, walaupun Belanda telah berkuasa atas Palembang sejak 1821, namun dari perkembangan fisik sampai menjelang awal abad ke-20 hampir tidak ada yang dibangun oleh pemerintah kolonial. Secara fisik kebijakan membangun Palembang baru dimulai setelah masa tiga belas tahun kemudian dari ditetapkannya sebagai gemeente. Mulai banyaknya orangorang Eropa yang hadir di Palembang, menimbulkan ide untuk diadakannya kota daratan diatas kota air bekas kesultanan. Hal pertama yang dilakukannya adalah membangun perumahan bagi warga Eropa.

Pada tahun 1933 setelah kedatangan Ir. Thomas Karsten, kawasan Talang Semut mulai berubah, kawasan ini direncanakan untuk pemukiman orang-orang Eropa, karena topografi tanahnya yang berbukitbukit (lebih tinggi dari kawasan lain). Bangunan yang sudah ada selain perumahan juga sekolah dan gedung pertemuan. Jalan utama yang ada adalah $\mathrm{Jl}$. $\mathrm{KH}$. Ahmad Dahlan (Jl. Boekit), Jl. Talang Kerangga, Oranyelaan (dahulu Jl. Talang Semoet, sekarang Jl. Aso Rochim), Willemslaan (sekarang Jl. Soepeno), Emmalaan (sekarang Jl. Ratna), Wilhelminulan (sekarang Jl. Diponegoro). Sedangkan Julianalan (sekarang JI. Kartini), Jl. Joko (Sophielaan) dan Jl. Talang Semut dahulunya adalah Jl. Tasik (vijverlaan).
Dalam tahap perencanaan jalan yang pertama dibangun adalah Nassaulaan (Jl. Merdeka) yang akan dibangun sebagai pusat pemerintahan (Lestari, 2003:75).

Pada masa kolonial, di kota Palembang dibangun sebuah pemukiman yang dikhususkan untuk warga keturunan Eropa dan kalangan elit lainnya yaitu di Talang Semut. Secara khusus kawasan ini didirikan seperti umumnya kawasankawasan pemukiman di Indonesia yang dibangun pada akhir abad XIX Masehi dan awal abad XX Masehi (Aryandini, 2002:3).

Sebagai kelompok penguasa pemerintah Hindia Belanda juga membangun sebuah kawasan pemukiman baru yang terpisah dari pemukimanpemukiman penduduk lainnya. Lokasi pemukiman tersebut berada di sebelah Barat kawasan pusat pemerintahan, yaitu Talang Semut (Aryandini, 2002:3).

Yang dimaksud dengan tanah talang pada masa kesultanan adalah tanah yang ada di kaki bukit. Menurut peta kolonial, daerah perbukitan itu membentang di Barat Daya Palembang, yaitu Bukit Seguntang ke arah tengah kota lewat Bukit Besar, Bukit Kecil, dan Bukit Gubah Penganten. Jadi selain daerah tersebut kota Palembang berada di tanah rawa-rawa di kaki bukitbukit tersebut muncul tanah-tanah agak tinggi yang disebut talang. Talang ini dimanfaatkan oleh pembesar keraton sebagai areal perkebunan durian, duku, rambutan, manggis, dan jambu. Tanah tinggi tersebut tidak dijadikan tempat tinggal dan untuk pergi ke kebun tersebut para petani penggarap menaiki perahu menyusuri sungai Sekanak (Aryandini, 2002:29).

Salah satu contohnya adalah alunalun Selatan bekas Keraton Kuto Lamo yang merupakan pusat kota Palembang digunakan sebagai pusat administrasi sekaligus sebagai simbol kekuasaan kolonial. Sampai 1920-an, pemerintah kota Palembang masih mempertahankan pemisahan tempat pemukiman berdasarkan perbedaan ras. Karena itu, ketika kebutuhan 
akan perumahan yang mendesak bagi orang Eropa di Palembang, maka pemerintah Gemeente Palembang atas rekomendasi pemerintah pusat di Batavia mengadakan pembangunan pemukiman agak ke Barat kota, yaitu Talang Semut yang jauh dari pemukiman penduduk pribumi.

Dapat disimpulkan berdasarkan pendapat diatas bahwa toponim kawasan Talang Semut berada di kaki Bukit Seguntang, tepatnya di daerah perbukitan yang berawal dari Bukit Seguntang ke arah tengah kota lewat Bukit Besar. Talang berarti tanah yang ada di kaki bukit.

\section{Kambang Iwak (KI)}

Kawasan Kambang Iwak masuk dalam kelurahan Talang Semut kecamatan Bukit Kecil yang terletak ditengah kota Palembang, Sumatera Selatan. Dengan luasan + $5000 \mathrm{~m}$, kawasan ini dibatasi oleh jalan Tasik dan berdampingan dengan beberapa kawasan penting, seperti rumah dinas Walikota Palembang, Hotel dan Gedung Serbaguna Swarna Dwipa, Gereja Siloam, serta kantor Dinas Pajak Palembang. Lokasi kawasan ini sangat strategis mengingat rute kendaraan pribadi maupun kendaraan umum yang dapat melintas di sekitar area ini. Masyarakat juga dapat mengakses kawasan Kambang Iwak dengan berjalan kaki ataupun bersepeda untuk menikmati pemandangan kolam serta taman yang indah (Utomo, 2015: 258) batas wilayah:

Utara : Permukiman penduduk dan rumah Dinas Walikota Palembang.

Timur : Jl. Dr. Sutomo, Kantor Dinas Perpajakan Sumatera Selatan.

Selatan: Jl. Tasik, Hotel dan Gedung Serbaguna Swarna Dwipa.

Barat : Permukiman Penduduk, Gereja Siloam.

Kambang Iwak merupakan peninggalan sejarah Belanda yang dibangun pada tahun 1921 semasa kepemimpinan Thomas Carlsen, Kambang Iwak hingga
Talang Semut sudah direncanakan sebagai taman kota. Pada era tahun 1930-an, kawasan Kambang Iwak masih berupa taman kota dengan konsep kebun binatang, dan disebut masyarakat sekitar dengan Kebun Binatang. Masyarakat dapat mengunjungi kawasan ini secara bebas, dan juga menyaksikan berbagai macam binatang pada kandang tertentu, mulai dari kelinci hingga rusa yang diletakkan pada spot-spot di kawasan Kambang Iwak. Hal ini bertujuan untuk memancing minat penduduk terhadap penggunaan ruang publik taman kota. Setelah kepengurusan Kambang Iwak tidak dalam kendali pemerintah Belanda lagi, pemeliharaan terhadap binatangbinatang tersebut mulai kurang diperhatikan, sehingga beberapa hewan tidak dapat bertahan dengan keadaan lingkungan buatan tersebut dan konsep kebun binatang bebas tidak dapat diterapkan lagi pada kawasan Kambang Iwak Palembang. Pemerintah Palembang pada saat itu tidak terlalu optimal memfungsikan Kambang Iwak, dan terbatas hanya pada fungsinya sebagai taman kota. Akibat dari tidak optimalnya penggunaan ruang publik ini, mengakibatkan penggunaan yang tidak layak oleh pengunjung, yang mengganggu keadaaan fisik maupun melanggar norma sosial dan susila di lingkungan tersebut. Keadaan ini terus bertahan hingga pertengahan tahun 2007, dimana mulai terdapat pembahasan baru mengenai penerapan fungsi komersial kedalam kawasan Kambang Iwak Palembang yang kemudian diwujudkan pada awal tahun 2008. Pemerintah kota Palembang mulai membangun fisik konsep baru dalam kawasan Kambang Iwak Palembang, berupa kawasan wisata kuliner, dengan nama baru yaitu KIF Park atau Kambang Iwak Family Park. Konsep ini menyajikan wisata kuliner khas Palembang ditengah keindahan suasana teduh dan asri Kambang Iwak Palembang yang bersejarah. Beberapa fasilitas mulai di perbaiki dan ditambah seperti air mancur, lampu hias, 
kursi outdoor, jogging track, anjungan, kioskios pedagang serta sarana permainan anak-anak. Dengan konsep ini, diharapkan akan semakin menguatkan peranan Kambang Iwak sebagai sarana publik space dalam wajah perkotaan Palembang (Utomo, 2015:230).

Menurut Sujiyati (2015:13) di kawasan Talang Semut terdapat tiga rawa besar. Sebelum dibangun perumahan, ada lahan yang perlu bernama Kolam Besar (Kambang Iwak) dan Kolam Kecil, di sekitar kedua kolam tersebut dibangun pula lokasi pemukiman orang-orang Eropa yang merupakan warga kelas satu. Sebagai lokasi yang dipilih adalah di sebelah Barat pusat pemerintahan. Selain diperuntukan untuk pejabat pemerintahan, rumah-rumah di kawasan ini juga disewakan untuk orangorang Eropa lainnya.

Dapat disimpulakan bahwa toponim kawasan Kambang Iwak mempunyai arti yakni Kambang artinya Kolam, sedangkan Iwak berasal dari bahasa Palembang artinya Ikan. Oleh karena itulah kawasan ini disebut Kambang Iwak.

\section{Soak Bato}

Kawasan Soak Bato terletak di keluarahan 26 llir kecamatan Bukit Kecil. Kawasan Soak Bato terdapat pasar yang diberi nama pasar Soak Bato. Bedasarkan wawancara dengan sejarawan Palembang, Soak berasal dari bahasa Palembang artinya Sungai, sedangkan Bato artinya bata. Maka dari itu pemberian nama Soak Bato diabadikan dengan nama kawasan, dahulu dikawasan ini terdapat sungai Soak Bato dan tempat pembuatan batu bata (Hasil wawancara tanggal 29 April 2018).

Kampung Soak Bato merupakan kota lama pada masa Kesultanan Palembang Darussalam. Masa pemerintahan Sultan Mahmud Baddarudin II. Di kawasan Kampung Soak Bato terdiri lingkungan istana (Masoed, 1941:35). Pada tahun 1811 ketika Belanda menutut balas atas kematian orang Belanda, Sultan Mahmud Baddarudin
II pun melarikan diri ke Musi Rawas, dan Palembang pun di kuasai oleh Belanda yaitu Jendral Gillespie dan mengangkat Sultan Ahmad Najamudin II menjadi sultan Palembang Darussalam. Ketika Sultan Ahmad Najamudin II mengirim utusannya untuk menjemput Sultan Mahmud Baddarudin II kembali ke Palembang, akhirnya sultan turutkan juga permintaan itu dan baginda kembali ke Palembang, duduk diatas tahta kerajaan Palembang seperti sediakala. Pada masa itu Sultan Ahmad Najamudin II (Pangeran Depati) pindah kembali ke kota lama di Soak Bato (Masoed, 1941:65).

Dapat disimpulkan bahwa toponim kawasan Soak Bato adalah sebuah anak sungai Sekanak. Soak adalah anak sungai yang berukuran kecil dan di kiri-kanannya sudah ditembok dengan batu bata. Dahulunya tempat usaha pembuatan batu bata, dari itulah kampung tersebut dinamakan Soak Bato. Pada masa kesultanan Palembang kawasan Soak Bato terdapat istana untuk peristrirahatan sultan.

\section{Kawasan Gubah}

Kawasan Gubah terletak di kelurahan Talang Semut kecamatan Bukit Kecil, tepatnya di Jl. KH. Ahmad Dahlan, lorong Gubah. Di kawasan Gubah terdapat sebuah pasar, pasar tersebut diberi nama pasar Gubah dan dibelakang pasar Gubah terdapat komplek makam Kesultanan Palembang Darussalam diantaranya makam Pangeran Ario Kusumo Bin Susuhan Ratu Husin Dhiauddin, Pangeran Adi Kusumo Abdul Hamid Bin Pangeran Ario Kusumo, Pangeran Haji Suta Dirajah (Pangeran Mudo) Bin Pangeran Ario Kusumo, makam Raden Samuddin Bin Pangeran Ario Kusumo, beserta makam keluarganya (Hasil observasi lapangan tanggal 18 Mei 2018).

Penamaan kawasan Gubah yang terletak di kelurahan Talang Semut di ambil dari komplek pemakaman kesultanan Palembang yang beratap Gubah, nama 
Gubah juga di abadikan dengan nama jalan dan nama pasar.

\section{Sungai Kapuran}

Sungai Kapuran merupakan sarana angkutan bahan semen untuk perekat bata dalam pembuatan Benteng Kuto Besak (BKB). Tiga anak sungai yang mengelilingi Benteng Kuto Besak yakni sungai Tengkuruk, sungai Sekanak dan sungai Kapuran, saat ini hanya tersisa sungai Sekanak, sungai Tengkuruk yang terletak di Jl. Jendral Sudirman dan sungai Kapuran yang terletak di Jl. Merdeka sudah ditimbun sejak masa pemerintahan Kolonial Hindia Belanda. Tempat penimbunan bahan kapur untuk perekat bata pada pembangunan Benteng Kuto Besak terletak di daerah belakang tanah keraton. Kuto besak adalah keraton pusat kesultanan Palembang, kompleks keraton ini di kelilingi oleh sungai dan parit yang sebelah utaranya mengalir sungai Kapuran (Laskarwongkito).

\section{Nilai-Nilai Perjuangan Kemerdekaan Indonesia Yang Bersumber Pada UUD 1945, NKRI, Pancasila, dan Bhinekka Tunggal lka Nilai Persatuan}

Persatuan bangsa adalah modal dasar yang sifatnya vital untuk mencapai tujuan bersama (Tujuan Nasional Indonesia). Persatuan bangsa ialah sesuatu kekuatan hubungan antar komponen bangsa dan merupakan kekuatan utama dalam dinamika kehidupan kebangsaan dan kenegaraan. Oleh itu ikatan persatuan bangsa harus dijaga agar tetap kokoh dan kuat, sehingga bangsa Indonesia menjadi semakin bersatu, tidak mudah cerai beraikan. Dengan demikian persatuan bangsa Indonesia merupakan salah satu kunci utama faktor penentu bagi modal pembangunan nasional (Lemhanas, 2016:27).

Dalam penelitian ini peneliti mendapatkan nilai persatuan yakni pada toponim kecamatan Bukit Kecil yakni di kawasan Benteng Kuto Besak (BKB). Benteng Kuto Besak merupakan benteng pertahanan pada masa Kesultanan Palembang Darussalam, dimana benteng ini menunjukan rasa persatuan masyarakat Sumatera Selatan dalam upaya mempertahankan Kesultanan Palembang dari Kolonialisme Barat yaitu Belanda.

Ketika terjadi pertempuran melawan Belanda maka seluruh masyarakat yang ada di lliran dan Uluan bersatu dalam mempertahankan Kesultanan Palembang Darussalam.

\section{Nilai Religius}

Nilai religius dalam keterkaitan individu dengan sesuatu yang dianggapnya memiliki kekuatan sakral, suci, agung, dan mulia. Memahami ketuhanan sebagai pandangan hidup adalah mewujudkan masyarakat yang berketuhanan, yakni membangun masyarakat Indonesia yang memiliki jiwa maupun semangat untuk mencapai ridho Tuhan dalam setiap perbuatan baik yang dilakukannya. Nilai religius memiliki nilai-nilai spiritual yang tinggi berdasarkan agama dan keyakinan yang dipeluknya, dan juga memiliki toleransi yang tinggi terhadap pemeluk agama dan keyakinan lain yang tumbuh serta diakui di Indonesia, ini konsekuensi dari nilai religius yang mengakui adanya Tuhan Yang Maha Esa. Menurut kamus bahasa, kata religius adalah kata kerja yang berasal dari kata berada religion. Arti dari relegi itu sendiri berasal dari kata raden ligere akhirnya adalah menghubungkan kembali yang telah putus, yaitu menghubungkan kembali tali hubungan antara tuhan dan manusia yang telah terputus dosa-dosanya (Lemhanas, 2016:12).

Dalam penelitian ini peneliti mendapatkan nilai religiusitas pada kawasan Cinde Welang, Guguk Pengulon dan kawasan Gubah. Pada kawasan Cinde Welan terdapat makam pendiri Kesultanan Palembang Darussalam yakni yakni Pangeran Ratu Kimas Hindi Sri Susuhan 
Abdurrahman Candi Walang Khalifatul Mukminin Sayidul Imam atau lebih dikenal Kimas Hindi/Kimas Cinde. Pada kawasan Guguk Pengulon nilai religiusnya yakni tempat atau kampung suatu profesi sebagai penghulu atau ahli agama para pendahulu dan alim ulama disekitaran masjid Agung. Sedangkan nilai religius yang terdapat pada toponim Gubah yang terletak di kelurahan Talang Semut yakni terdapat komplek pemakaman Kesultanan Palembang diantaranya makam Pangeran Ario Kusumo bin Susuhan Ratu Husin Dhiauddin, Pangeran Adi Kusumo Abdul Hamid Bin Pangeran Ario Kusumo, Pangeran Haji Suta Dirajah (Pangeran Mudo) Bin Pangeran Ario Kusumo, makam Raden Samuddin Bin Pangeran Ario Kusumo, beserta makam keluarganya.

\section{Relevansi Nilai Sejarah Toponim di Kecamatan Bukit Kecil sebagai Sumber Pembelajaran Sejarah di SMP Negeri 33 Palembang}

Adapun strategi yang dipakai oleh peneliti untuk menjadikan nilai sejarah toponim di kecamatan Bukit Kecil sebagai sumber pembelajaran sejarah lebih dahulu harus mengetahui serta paham akan kurikulum yang diterapkan di SMP Negeri 33 Palembang. Setelah itu peneliti harus mencari silabus yang sesuai dengan kurikulum di sekolah, dan mencari materi yang sesuai dengan materi nilai sejarah toponim. Kurikulum yang dipakai oleh SMP Negeri 33 Palembang adalah Kurikulum 2013.

Ketika kita menjadi seorang guru, guru tersebut haruslah memahami materi pelajaran IPS/sejarah yang akan ia ajarkan kepada peserta didik, namun sebelumnya seorang guru harus membuat ringkasan materi, dan harus banyak membaca agar menambah pengetahuan dalam mengajar. Sedangkan pelaksanaan pembelajaran IPS di SMP Negeri 33 Palembang berjalan dengan kurikulum yang telah ditentukan oleh pemerintah.
Menurut ibu Emi, untuk memahami materi pembelajaran khususnya materi tentang sejarah toponim suatu tempat, seorang guru harus banyak membaca dokumen-dokumen yang berhubungan dengan materi yaitu sejarah toponim atau tentang sejarah lokal daerah tersebut dan juga harus banyak bertanya kepada sejarawan-sejarawan yang mengetahui tentang sejarah toponim yang berkaitan dengan sumber pembelajaran. Kemudian untuk menerapkan materi pembelajaran IPS Terpadu tentang nilai sejarah toponim, harus ada pemilihan materi pembelajaran yang sesuai dengan kompetensi dasar yang sudah ada di dalam kurikulum, setelah materi pembelajaran ditentukan maka dapat dikembangkan dalam kegiatan pembelajaran. Sejarah toponim atau sejarah suatu kawasan yang ada di kecamatan Bukit Kecil termasuk pada Kompetensi Dasar: 3.4. Menganalisis kronologi, perubahan dan kesinambungan ruang (geografis, politik, ekonomi, pendidikan, sosial, budaya) dari masa penjajahan sampai tumbuhnya semangat kebangsaan. Materi pembelajaran: Perubahan dan kesinambungan (geografis, politik, ekonomi, pendidikan, sosial, budaya) masyarakat Indonesia pada masa penjajahan (Catatan wawancara tanggal 1 Mei 2018).

Jadi materi tentang sejarah toponim atau sejarah suatu kawasan yang ada di kecamatan Bukit Kecil dapat dijadikan sebagai sumber pembelajaran IPS Terpadu khususnya materi sejarah pada kelas VIII semester II. Dalam kegiatan pembelajaran sejarah toponim di kecamatan Bukit Kecil tujuannya agar siswa lebih mengetahui lagi akan sejarah lokal yang ada kota Palembang khususnya di kecamatan Bukit Kecil, dan juga dapat meningkatkan rasa nasionalisme dan rasa kepedulian terhadap daerah tersebut.

\section{SIMPULAN}

Toponim merupakan sebuah ilmu yang berkaitan dengan penamaan suatu 
wilayah yang berguna memberikan informasi kepada masyarakat tentang asal usul penamaan suatu tempat tersebut. Toponim suatu daerah merupakan identitas yang membedakannya dengan daerah lain. Pemberian nama oleh manusia mempermudah dalam mengindentifikasi suatu tempat tinggalnya, pemberian nama ini tidak asal diberikan karena manusia memberikan nama suatu tempat atau kawasan berdasarkan letak geografis, sejarah dan fenomena alam yang terjadi di tempat itu. Tata cara pembakuan pemberian nama pada unsur geografis dan peristiwa masa lalu ternyata tidak sesederhana perkirakan banyak orang, tata cara untuk menstandarisasi dan mengatur penamaan suatu unsur geografis dikaji dan diatur dalam suatu cabang ilmu yang dikenal sebagai toponimi. Sistem penamaan tempat adalah tata cara atau aturan memberikan nama tempat pada waktu tertentu.

Kecamatan Bukit Kecil merupakan salah satu kawasan pemukiman lama yang ada di kota Palembang. Baik masa Kesultanan Palembang Darussalam maupun masa Kolonial. Banyak terdapat toponim di kecamatan Bukit Kecil yang memiliki nilai sejarah sehingga dapat dimanfaatkan sebagai sumber pembelajaran sejarah. nilai-nilai tersebut diantaranya, nilai perjuangan, nilai religius dan nilai persatuan. Nilai-nilai yang dikemukakan diatas dapat memberikan pengetahuan dan pembelajaran terhadap masyarakat umumnya dan peserta didik khususnya.

\section{DAFTAR PUSTAKA}

Aryandini, Novit. 2002. "Pola pemukiman dikawasan Talang Semut kota Palembang". Dalam Siddhayatra. Tim Arkeologi (Ed). Volume 7, Nomor 2, 2002).

Elvian, Akhmad. 2009. Toponim Kota Pangkal Pinang. Pangkal Pinang: CV. Franita.

Farida. 8 Mei 2013. Kuto Besak dari Keraton Menjadi Benteng. Majalah Unsri.
Rais, Jacub. 2008. Toponimi Indonesia: Sejarah Budaya yang Panjang Dari pemukiman Manusia dan Tertib Administrasi. Jakarta: Pradnya Paramita.

Jeko, Ruspandi dan Asep Mulyadi. 2014. "Fenomena Geografis Dibalik Makna Toponimi Kota Cirebon". Dalam Gea. Volume 14, Nomor 23, 2014).

Lemhanas RI. 2017. Nilai Nilai yang Bersumber dari NKRI. Jakarta: Kedeputian Bidang Pemantapan Nilai-Nilai Kebangsaan Lemhanas RI. . 2017. Nilai Nilai yang Bersumber dari Pancasila. Jakarta: Kedeputian Bidang Pemantapan Nilai-Nilai Kebangsaan Lemhanas RI.

Mas'oed, Ki Agoes. 1941. Sedjarah Palembang Moelai Sedari Seri-Wijaya Sampai Kedatangan Dai Nippon. Palembang: Meroeyama.

Sujiyati, Maryani dan Nor Huda Ali. 2015. "Pembangunan kota Palembang dengan konsep tata ruang kota hijau pada masa Hindia-Belanda". Dalam Tamaddun. Volume 15, Nomor 1, 2015).

Santun, Dedi Irwanto Muhammad, dkk. 2010. Iliran dan Uluan: Dinamika dan Dikotomi Sejarah Kultural Palembang. Plaembang: Eja Publisher.

Utomo, Bambang Budi. 2016. Peradaban Masa Lalu Sumatera Selatan. Palembang: Balai Arkeologi Sumatera Selatan.

Lestari, Sri Endang. 2003. Karakteristik Pola Tata Ruang Karsten Pada Kawasan Talang Semut Palembang. Tesis. Yogyakarta: Universitas Diponegoro.

\section{Internet}

Konfrontasi.com/content/ragam/makam-rajapalembang-di-candi-walangmemprihatinkan, diakses pada tanggal 10-05-2018 pukul 19:20 Wib.

Aryandininovita.blogspot.co.id/2012/04/sum berdaya-arkeologi-di-kawasan- 
benteng.html?m=1. Diakses pada tanggal 11-052018 pukul 21:11 Wib.

Laskarwongkito.

2016.

Https://www.laskarwongkito.com/limasungai-bersejarah-di-palembang-

yang-kini-butuh-perhatian-kitasemua/\&hl=id-ID diakses pada 15 Mei 2018 pukul 15.46 Wib.

\section{Wawancara Lapangan}

Hasil observasi lapangan tanggal 18 Mei 2018. Pukul 15.15 Wib.

Wawancara dengan Muhammad Idris, M.Pd, pada tanggal 29 April 2018. Pukul 13.30 Wib. 


\section{KETENTUAN PENULISAN ARTIKEL JURNAL KALPATARU}

1. Naskah berbahasa Indonesia yang disempurnakan bertemakan kesejarah yang meliputi hasil penelitian sejarah, pengajaran sejarah dan penelitian kebudayaan.

2. Naskah harus asli dan belum pernah dimuat dalam media lain. Naskah dapat berupa hasil penelitian/artikel kajian konseptual yang ditulis oleh perorangan dan atau kelompok.

3. Naskah ditulis dengan cara-cara yang sesuai dengan ketentuan penulisan artikel ilmiah menggunakan bahasa Indonesia yang baku, berupa ketikan, beserta soft file dalam CD-RW atau dengan mengirimkan email pada redaksi jurnal Kalpataru dengan alamat jurnalkalpatarusejarah@gmail.com, spasi tunggal, jenis huruf arial narrow ukuran 12, dengan panjang naskah antara 8-15 halaman pada kertas A4.

4. Artikel hasil penelitian memuat:

JUDUL

Nama Penulis

Abstrak

\section{A. PENDAHULUAN}

B. METODE PENELITIAN

C. HASIL DAN PEMBAHASAN

D. SIMPULAN

DAFTAR PUSTAKA
: XXX (HURUF KAPITAL)

: (disertai jabatan, institusi, dan email)

: (Bahasa Indonesia yang memuat 100-200 kata diikuti kata kunci, dengan jenis huruf arrial narrow dan ukuran huruf 11 serta dicetak miring).

: (memuat latar belakang masalah, tinjauan pustaka secara ringkas, masalah penelitian, dan tujuan penelitian).

: (berisi simpulan).

: (berisi pustaka yang dirujuk dalam uraian naskah).

5. Artikel Kajian Konseptual memuat:

\section{JUDUL \\ Nama Penulis \\ Abstrak \\ PENDAHULUAN \\ Sub Judul \\ Simpulan \\ DAFTAR PUSTAKA}

: XXX (HURUF KAPITAL)

: (disertai jabatan, institusi, dan email)

: (Bahasa Indonesia yang memuat 100-200 kata diikuti kata kunci, dengan jenis huruf arrial narrow dan ukuran huruf 11 serta dicetak miring.

: (memuat latar belakang masalah, tinjauan pustaka secara ringkas, masalah penelitian, dan tujuan penelitian).

: Sesuai dengan kebutuhan (tanpa numbering).

: (berisi simpulan dan saran).

6. Referensi sumber dalam teks artikel ditulis dengan menggunakan side note, contoh (Jalaludin, 1991:79); sementara penulisan daftar pustaka disusun dengan ketentuan. Nama pengarang. Tahun terbit. Judul (dicetak miring). Kota terbit: Nama Penerbit. Contoh: Koentjaraningrat. 2010. Manusia dan Kebudayaan di Indonesia. Jakarta: Djambatan. Daftar pustaka hanya memuat pustaka/sumber yang dirujuk dalam uraian dan disusun menurut abjad tanpa nomor urut.

7. Naskah yang dimuat akan disunting kembali oleh redaksi tanpa mengubah isinya.

8. Naskah yang ditolak (tidak bisa dimuat) akan dikirim kembali ke penulis dengan pemberitahuan tertulis dari redaksi atau melalui email.

9. Penulis yang naskahnya dimuat akan mendapat 1 (satu) majalah nomor yang bersangkutan.

10. Kontak person: Muhamad Idris (081271498618); Eva Dina Chairunisa (082281267851); Jeki Sepriady (085269261780). 